\title{
Year-round lamb production in the Manawatu region - results from year one
}

\author{
S.T. MORRIS, P. C. H. MOREL, P. R. KENYON, P. D. KEMP, D.L. BURNHAM, D. M. WEST, \\ S. W. M. PETERSON, D.I. GRAY, I. SCOTT and W.E. POMROY \\ College of Sciences, Massey University, PB 11222, Palmerston North \\ S.T.Morris@massey.ac.nz
}

\begin{abstract}
Four hundred and eighty East Friesian composite (50\% East Friesian, 25\% Poll Dorset, 25\% Texel) or Romney ewes were assigned to either a conventional lambing (March) group or a year-round lambing group. The trial began in January 2003 and the year-round system aims to have ewes lambing every 73 days. In the year-round system approximately a third of the ewes were synchronised and joined with mixed age rams of their respective breed for a 21 day period on 13 January, 27 March, 8 June, 21 August and 1 November. This results in each ewe having the opportunity to lamb five times in a three-year period. The conventionally bred ewes were joined with rams on 27 March for 2 cycles of breeding. Results after year one indicate the number of lambs born and weaned per ewe lambing was similar for East Friesian ewes in the year-round and conventional lambing groups. However Romney ewes reared less lambs (1.22 vs 1.41, $\mathrm{P}<0.05)$ than East Friesian composite ewes in the conventional system. Pregnancy rates at scanning were higher in East Friesian composite than Romney ewes in the year-round system $(0.75$ vs $0.65, \mathrm{P}<0.05)$ but there were no differences between the two breeds in the conventional system. Lamb birth weights were heavier in the conventional system than the year-round system $(5.1 \pm 0.1 \mathrm{~kg}$ vs $4.2 \pm 0.1 \mathrm{~kg}$ and $4.8 \pm 0.1 \mathrm{~kg}$ vs $4.1 \pm$ $0.1 \mathrm{~kg}$ for East Friesian and Romney ewes respectively). Lambs born in June were significantly lighter than lambs born in August or November in the all year-round system. Lamb growth rates and weaning weights of lambs born to East Friesian composite dams were heavier than lambs born to Romney dam in both systems. The major constraint that appears to be limiting high performance in the year-round system is the low pregnancy rates in the non-breeding season (i.e. August to January). Based on year one data it can be concluded that income from lamb sales in the year-round system can match or better (in the case of East Friesian composite ewes) a conventional March lambing system without any premiums for the out-of-season lambs and is likely to be further improved if pregnancy rates can be improved.
\end{abstract}

Keywords: lamb growth, lamb production, number of lambs born, year-round lambing

\section{Introduction}

In New Zealand, ewes are mated in the autumn so that they lamb at the beginning of the spring pasture growth period, to produce lambs for slaughter through the summer and autumn period. Increased production levels in the sheep farming sector in recent years has been achieved through increasing fecundity and lambing percentages. A proportion of the industry may, however have reached a plateau at 200 percent lambing with a significant proportion of triplets potentially resulting in large lamb losses (Morris et al. 2003). Changing from once-a-year to a year-round lambing system could potentially increase profitability on high-performing sheep farms.

Internationally, inducing ewes to lamb more than oncea-year is not unusual but it is generally confined to intensive, inside wintering systems (Gordon 1997). While the idea was suggested in New Zealand at least 10 years ago (McCutcheon et al. 1993), it has never been fully tested in an outdoor pastoral based system. Preliminary modelling indicates a year-round lambing system has potential financial advantages under certain scenarios (Morel et al. 2004).

In recent years there has been increasing interest in the development of "out-of-season" lambing systems. To date, however, these have concentrated mainly with the production of "early" (winter) lambing systems, rather than with the development of a year-round lamb production system. Most of the research into out-ofseason lamb production in New Zealand has examined a once yearly system outside the normal period for a given region (Andrewes \& Taylor 1986; Lowe et al. 1988; Reid et al. 1988; Knight et al. 1989; Smith et al. 1992; Morris et al. 1993).

The choice of method for obtaining out-of-season lambs will depend on the planned date of lambing. For example late season lambs could be produced by mating hoggets while autumn lambs can be produced by using controlled internal drug releasing devices (CIDRS) plus pregnant mares serum gonadotrohophin (PMSG) (Knight et al. 1989). Changing to a breed of sheep that has an extended breeding season may be the preferred option but as yet this is not a reality in New Zealand, as no breed will uniformly breed all year round.

Increasing the frequency of lambing within a 12-month period is referred to as "accelerated lambing", "multiple lambing" or "twice yearly lambing". There is some reference to twice-yearly lamb production in the literature (Rattray 1974, 1975). A twice-a-year lambing system is 
Table 1 Effect of year-round and conventional lambing on ewe liveweight $(\mathrm{kg})$ at mating and pre-lambing for East Friesian composite (EF) and Romney ewes (RM) (means \pm SE's).

\begin{tabular}{|c|c|c|c|c|}
\hline \multirow{2}{*}{$\begin{array}{l}\text { Lambing } \\
\text { group }\end{array}$} & \multicolumn{2}{|c|}{ EF } & \multirow{2}{*}{ Mating RM } & \multirow[b]{2}{*}{ Pre-lambing } \\
\hline & Mating & Pre-lambing & & \\
\hline \multicolumn{5}{|l|}{ Year-round } \\
\hline June & $67.6(1.3)^{a 4}$ & $69.1(1.5)^{\mathrm{a} 23}$ & $57.4(1.5)^{\mathrm{b} 34}$ & $61.8(2.0)^{b 1}$ \\
\hline August & $56.7(1.2)^{\text {a12 }}$ & $62.2(1.4)^{1}$ & $52.4(1.2)^{b 12}$ & $61.0(1.4)^{1}$ \\
\hline November & $54.7(1.3)^{1}$ & $72.2(1.5)^{34}$ & $54.5(1.1)^{23}$ & $70.2(1.3)^{2}$ \\
\hline January & $61.2(1.3)^{3}$ & $77.3(2.0)^{\text {a } 5}$ & $60.4(1.5)^{4}$ & $69.8(2.6)^{\text {b2 }}$ \\
\hline March & $66.5(1.1)^{4}$ & $73.3(1.6)^{45}$ & $66.5(1.0)^{5}$ & $70.1(1.9)^{2}$ \\
\hline All & $61.7(0.6)^{\mathrm{ax}}$ & $69.8(0.7)^{\mathrm{ax}}$ & $58.5(0.6)^{b x}$ & $66.2(0.8)^{\mathrm{bx}}$ \\
\hline Conventional & $58.2(0.7)^{\text {a2y }}$ & $67.1(0.8)^{\mathrm{a} 2 y}$ & $51.6(0.7)^{\text {b1y }}$ & $59.8(0.8)^{b 1 y}$ \\
\hline
\end{tabular}

Table 2 The effect of year-round and conventional lambing on ewe pregnancy rate (\%) for East Friesian composite (EF) and Romney (RM) ewes.

\begin{tabular}{lll}
\hline Lambing group & EF & RM \\
\hline Year-round & & \\
June & 71 & 47 \\
August & 98 & 91 \\
November & 97 & 92 \\
January & 60 & 46 \\
March & 57 & 42 \\
All & $75^{\text {b1 }}$ & $65^{\mathrm{a}}$ \\
Conventional & $96^{2}$ & $96^{2}$ \\
\hline
\end{tabular}

$a, b$ indicates difference between breed within system (Chi-squared $\left.\left(X^{2}\right), P<0.05\right)$.

1,2 indicates differences between system group within breed (Chi-squared $\left.\left(\chi^{2}\right), P<0.05\right)$.

Table 3 Effect of year-round and conventional lambing on number of lambs born (NLB) and number of lamb weaned (NLW) for East Friesian composite (EF) and Romney ewes (RM).

\begin{tabular}{|c|c|c|c|c|}
\hline \multirow{2}{*}{$\begin{array}{l}\text { Lambing } \\
\text { group }\end{array}$} & \multicolumn{2}{|c|}{$\mathrm{EF}$} & \multicolumn{2}{|c|}{$\mathrm{RM}$} \\
\hline & NLB & NLW & NLB & NLW \\
\hline \multicolumn{5}{|l|}{ Year-round } \\
\hline June & $1.97^{\mathrm{a}}$ & $1.65^{\mathrm{a} 2}$ & $1.42^{\mathrm{b}}$ & $1.16^{\mathrm{b}}$ \\
\hline August & 1.58 & $1.33^{1}$ & 1.52 & 1.10 \\
\hline November & 1.50 & $1.36^{12}$ & 1.39 & 1.30 \\
\hline January & 1.77 & $1.61^{2}$ & 1.45 & 1.18 \\
\hline March & 1.66 & $1.25^{1}$ & 1.50 & 1.46 \\
\hline All & $1.68^{\mathrm{a}}$ & $1.42^{\mathrm{a}}$ & $1.46^{\mathrm{b}}$ & $1.22^{\mathrm{bx}}$ \\
\hline Conventional & 1.57 & 1.26 & 1.53 & $1.41^{y}$ \\
\hline
\end{tabular}

difficult as the ewe has to be mated in the first month after lambing. An alternative system that has been tried in North America is five lambings in three years called the "star (year-round system)" (Hogue 1987; McCutcheon et al. 1993).

The focus of the trial reported here is to provide proof of the concept of a year-round pasture based lamb production system using five lambings in three years.

\section{Method}

Four hundred and eighty mixed aged ewes comprising equal numbers of East Friesian composite (stabilized at 
Table 4 The effect of year-round and conventional lambing on lamb birth and weaning weight (kg) and liveweight gain (ADG/day) from birth to weaning for lambs born to East Friesian Composite (EF) and Romney $(\mathrm{RM})$ ewes (Mean $\pm \mathrm{SE})$.

\begin{tabular}{|c|c|c|c|c|c|c|}
\hline \multirow{2}{*}{$\begin{array}{l}\text { Lambing } \\
\text { group }\end{array}$} & \multicolumn{3}{|c|}{$\mathrm{EF}$} & \multicolumn{3}{|c|}{$\mathrm{RM}$} \\
\hline & Birth LW & Wean LW & ADG & Birth LW & Wean LW & ADG \\
\hline \multicolumn{7}{|l|}{ Year-round } \\
\hline June & $3.89(0.14)^{1}$ & $17.1(0.8)^{a 1}$ & $229(9)^{\text {a2 }}$ & $3.55(0.20)^{12}$ & $13.9(1.1)^{b 1}$ & $191(12)^{\mathrm{b} 2}$ \\
\hline August & $4.29(0.14)^{2}$ & $21.6(0.8)^{\text {a3 }}$ & $257(9)^{\text {a3 }}$ & $4.32(0.14)^{34}$ & $18.4(0.8)^{b 2}$ & $224(9)^{\text {b3 }}$ \\
\hline November & $4.77(0.15)^{3}$ & $23.0(0.8)^{3}$ & $256(9)^{3}$ & $4.60(0.15)^{45}$ & $23.4(0.8)^{3}$ & $272(9)^{4}$ \\
\hline January & $3.98(0.15)^{a 12}$ & $18.4(0.8)^{a 12}$ & $198(9)^{a 1}$ & $3.44(0.18)^{b 1}$ & $13.9(1.0)^{b 1}$ & $144(12)^{b 1}$ \\
\hline March & $4.22(0.14)^{12}$ & $19.0(0.1)^{2}$ & $206(8)^{1}$ & $3.94(0.19)^{23}$ & $18.2(0.9)^{2}$ & $202(10)^{3}$ \\
\hline All & $4.20(0.09)^{x}$ & $19.7(0.6)^{\mathrm{ax}}$ & $226(6)^{a x}$ & $4.09(0.10)^{x}$ & $18.5(0.6)^{\mathrm{ax}}$ & $214(7)^{b}$ \\
\hline Conventional & $5.06(0.10)^{\text {азу }}$ & $30.4(0.7)^{a 4 y}$ & $260(8)^{\text {азу }}$ & $4.80(0.11)^{b 5 y}$ & $26.0(0.7)^{b 4 y}$ & $222(8)^{b 3}$ \\
\hline \multicolumn{7}{|c|}{$\begin{array}{l}\left.{ }^{\mathrm{ab}} \text { indicate differences between breed within mating group (LSD, } P<0.05\right) \text {. } \\
{ }^{12345} \text { indicates differences between mating group within breed (LSD, } P<0 \text {. }\end{array}$} \\
\hline
\end{tabular}

Table 5 Effect of year-round and conventional lambing on lamb number, weight and value of lambs sold over a 12 month period from a 20 ha farmlet.

\begin{tabular}{|c|c|c|c|c|}
\hline & \multicolumn{2}{|c|}{ EF } & $\longrightarrow \mathrm{RN}$ & 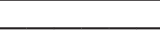 \\
\hline & Conventional & Year-round & Conventional & Year-round \\
\hline Total number of ewes joined ${ }^{1}$ & 118 & 206 & 121 & 193 \\
\hline Total number of ewes lambed & 102 & 161 & 97 & 134 \\
\hline No lambs born & 161 & 270 & 149 & 195 \\
\hline No lambs weaned & 129 & 228 & 137 & 164 \\
\hline Kg lamb sold & 4091 & 4915 & 3731 & 3676 \\
\hline$\$$ income /20 ha (\$2 per $\mathrm{kg})$ & 8182 & 9830 & 7462 & 7354 \\
\hline
\end{tabular}

${ }^{1}$ Ewes joined for conventional were 239 from 20 ha while on year-round it was 399 from 20 ha which equates to 1.65 joinings/ewe/year.

50\% East Friesian, 25\% Poll Dorset and 25\% Texel) and Romney ewes were divided equally into either a conventional or a year-round lambing system, each on a 20 ha area.

In the year-round system ewes were initially divided into 3 flocks and approximately 40 ewes of each breed were joined with mixed age rams of their respective breed or cross (at a ram/ewe ratio of 1:10) for a 21 day period on 13 January, 27 March, and 8 June. Ewes from the January breeding that became pregnant lambed from 8 25 June and were again joined with rams on 21 August after weaning of their lambs (average age, 70 days). Ewes from the March breeding lambed from 21 August to 10 September and were again joined with the ram for a second time on 1 November. Ewes pregnant from the June breeding lambed from 1 November to 20 November and were joined with ram again on 13 January 2004. Ewes that failed to get pregnant at each joining were retained to the next joining period. Ewes in the yearround system were synchronised at each of the five matings using CIDR's together with PMSG used at a rate of 400 IU for the 13 January joining period and 800 IU for the 21 August and 1 November joining period
(Knight et al. 1989).

The conventional ewe group were joined with rams for two cycles (at a ram/ewe ratio of 1:80) on 27 March. Ewe hogget replacements were included in both the yearround and conventional systems. They entered the yearround system and were joined with the ram at approximately one year of age at either the August or November joining periods and are joined with the ram at 9 months of age in the conventional system. Male and surplus female lambs are sold at weaning at an average age 70 days for year-round and 100 days for conventionally bred lambs.

Feed demands are met using brassica feed crops in summer (6ha on each of the conventional and year-round system) and winter active annual ryegrasses during winter (6ha on each system). Therefore during the winter there was 14 ha of permanent pasture and 6 ha of annual ryegrass. Likewise in summer there was 6 ha of brassica feed crops and 14 ha of permanent pasture to match feed demand and supply.

A linear model with breed and lambing group as fixed effects and their interaction was fitted to ewe live weight and number of lambs born and weaned per ewe lambing, 
lamb birth and weaning weight and growth rate data. Lamb birth weight, weaning weight and growth rate data were corrected for sex and birth rank effects (PROC GLM, SAS 1999). Pregnancy data were analysed by contingency table and Chi-square procedure (PROC FREQ, SAS 1999).

\section{Results}

Mean ewe live weight for the various lambing groups are presented in Table 1. The East Friesian composite ewes were significantly $(\mathrm{P}<0.05)$ heavier on average than Romneys by $3.2 \mathrm{~kg}$ and $6.6 \mathrm{~kg}$ at ram joining and $3.6 \mathrm{~kg}$ and $7.3 \mathrm{~kg}$ prior to lambing for the year-round and conventionally bred ewes, respectively. There were significant $(\mathrm{P}<0.05)$ live weight differences between each mating group within a breed and between breeds for the average live weight of ewes in the year-round lambing system.

Pregnancy rates at scanning were higher in East Friesian composite than in Romney ewes in the yearround system but there were no differences between the two breeds in the conventional system. Overall pregnancy rates were significantly $(\mathrm{P}<0.05)$ lower in the year-round than the conventional system by 21 and $31 \%$ for East Friesian and Romney ewes, respectively (Table 2).

Numbers of lambs born and weaned per ewe lambing were similar between lambing systems (Table 3). However East Friesian composite ewes reared significantly $(\mathrm{P}<0.05)$ more lambs than Romney ewes in the conventional lambing group (1.41 vs 1.22 lambs reared per ewe lambing, respectively).

Lambs born to East Friesian and Romney ewes in the conventional system were significantly $(\mathrm{P}<0.05)$ heavier than lambs born to East Friesian or Romney ewes lambing year-round $(5.06 \pm 0.1 \mathrm{~kg}$ and $4.8 \pm 0.1 \mathrm{~kg}$ vs $4.2 \pm 0.1 \mathrm{~kg}$ and $4.1 \pm 0.1 \mathrm{~kg}$ respectively). Lamb growth rates and weaning weights of lambs born to East Friesian composite dams were heavier than Romney lambs in both systems of lambing (Table 4). Average lamb weaning weights were significantly $(\mathrm{P}<0.05)$ heavier in the conventional system than the year-round system.

\section{Discussion}

The total number of ewes that lambed (from the original 240 per group) over a 12 month period were 295 and 199 for the year-round and conventionally bred ewes, respectively (Table 5). The lower average conception rates of 0.75 in the year-round system was more than compensated by increased frequency of lambing.

Lamb production over the 12 month period, indicates that the year-round system has produced more lambs but at lighter weights (Table 5). When lamb live weight is valued at $\$ 2.00$ per $\mathrm{kg}$ in both systems, returns per $20 \mathrm{ha}$ farmlet were higher in the year-round system for East
Friesian composite ewes and similar between the two systems for Romney ewes. This suggests that the East Friesian composite is more suited to an all-year round lambing system than the Romney.

The major constraint that appears to be limiting high performance in the year-round system is the low pregnancy rates in the non-breeding season (i.e. August to January) and the lower than expected lamb average weaning weights in some lambing groups. After the first year of the trial, the income from lamb sales in the yearround system would have matched or bettered (in the case of East Friesian composite ewes) a conventional March lambing system without any premiums for the out-of-season lambs. Future profitability calculations should estimate the extra labour required in the yearround system. Further work is also required to devise optimal feeding strategies for lactating ewes at various times of the year.

\section{ACKNOWLEDGEMENTS}

The Riverside Farm Research Fund, The C Alma Baker Trust and Meat and Wool Innovation funded the trial. $\mathrm{Mr}$ Peter Jessop is acknowledged for his expert husbandry of the ewes in the trial

\section{REFERENCES}

Andrewes, W.G.K.; Taylor, A.O. 1986. Autumn and winter lambing strategies in Northland. Proceedings of the New Zealand Grasslands Association 47: 81-88. Fahmy, M.H. 1990. The accumulative effect of Finn sheep breeding in crossbreeding schemes: ewe productivity under an accelerated lambing system. Canadian Journal of Animal Science 70: 967- 974.

Gordon, I. F. 1997. Controlled reproduction in sheep and goats. Controlled reproduction in farm animals series Volume 2. CAB International, Wallingford. $456 \mathrm{pp}$.

Hogue, D.E. 1987. Frequent lambing systems. pp. 57 64. In: New techniques in sheep production. Eds. Marai, I.F.M; Owen, J.B. Butterworth, London, UK. Knight,T.W.; McMillan,W.H.; Kannegieter,S.G.; Sorrenson,E. S.; Ridland,C.J.; Gibb, M.1989. Mating Romney ewes in November-December using CIDRs and pregnant mare serum gonadotrophin. Proceedings of the New Zealand Society of Animal Production 49: 255-260.

Lewis, R.M.; Notter, D.R.; Hogue, D.E.; Magee, B.H. 1996. Ewe fertilty in the STAR accelerated lambing system. Journal of Animal Science 74: 1511-1522.

Lowe, K I. ; Carter, M.L. ; McCutcheon, S.N. 1988. Development of systems for out-of-season lambing at Limestone Downs. Proceedings of the New Zealand Society of Animal Production 48: 95-98.

McCutcheon, S.N.; Morris, S.T.; Hogue, D.E. 1993. 
Year-Round Lamb Production: What can we learn from the "star"system? Proceedings of the Central Districts Sheep and Beef Cattle Farmers 'Conference 4: 49-54.

Morel, P.C.H.; Kenyon, P.R.; Morris, S.T. 2004. Economical analysis of year round lamb production. Proceedings of the New Zealand Society of Animal Production 64: 179-182.

Morris, S.T.; Blair, H.T.; Parker, W.J.; McCutcheon, S.N. 1993. Evaluation of Border Leicester x Romney (BR), Poll Dorset x BR, and Suffolk x BR ewes for out-of-season lambing. New Zealand Journal of Agricultural Research 36: 349-362.

Morris, S.T.; Kenyon, P.R.; Burnham, D.L.; EverittHincks, J.L. 2003. The effect of sward height on twin and triplet lamb birth weights and survival rates to weaning. Proceedings of the New Zealand Society of Animal Production 63: 152-154.
Rattray, P. V. 1974. Nutritional and husbandry problems involved in a system of twice-yearly lambing. New Zealand Ministry of Agriculture and Fisheries, Agricultural Division Annual Report 1973/74: 48.

Rattray P. V. 1975. Twice-yearly lambing. New Zealand Ministry of Agriculture and Fisheries, Agricultural Division Annual Report 1974/75: 46.

Reid, T.C.; Sumner, R.M.W.; Wilson, L.D. 1988. Performance parameters in an autumn lambing ewe flock. Proceedings of the New Zealand Society of Animal Production 48: 91- 94.

SAS 1999. Statistical Analysis System, Release 7, SAS. Inst. Inc. Cary, NC, USA.

Smith, J.F.; Johnson, D.L.; Reid, T.G. 1992. Genetic parameters and performance of flocks selected for advanced lambing date. Proceedings of the New Zealand Society of Animal Production 52:129-131. 
